\title{
Analyzing types of classroom interaction in CLIL
}

\begin{abstract}
The following article presents a study on interaction in a Content and Language Integrated Learning classroom. Starting with a brief description of van Lier's interaction framework, and a general overview of the qualitative studies, the article focuses particularly on the description and analysis of various types of interaction as well as their functions observed in a CLIL classroom.
\end{abstract}

KEYWORDS: CLIL, Content and Language Integrated Learning, bilingual education, interaction, language classroom.

\section{INTRODUCTION}

Interaction in the classroom is not random. The matter of who speaks and when is often governed by certain regulations. According to Hall and Walsh (2002) "classroom interaction takes on an especially significant role in that it is both the medium through which learning is realized and an object of pedagogical attention" (Hall, Walsh 2002: 186-203). Hall and Verplaetse (2002) claim that "it is in their interactions with each other that teachers and students work together to create the intellectual and practical activities that shape both the form and the content of the target language as well as the processes and outcomes of individual development" (Hall, Verplaetse 2000: 10). Interaction between the teacher and the learners as well as the learners themselves is crucial in the CLIL classroom as in any classroom. In fact, CLIL can be seen as a positive action. Fruhauf, Coyle and Christ (1996) claim that CLIL is a positive action as it brings the learners together and help preparing them for more intensive team-work skills and cooperation later in their courses. In the CLIL context, the teachers also need to show and communicate with the learners in a greater range of ways in order to support content and language learning. 


\section{THE AIM}

In my article, I am going to describe and analyse classroom interaction between CLIL teachers and CLIL learners as well as among CLIL learners themselves. The empirical study was conducted for a period of one school year in a secondary school in Krakow where subjects such as geography, biology and mathematics were offered in English. I strongly believe that classroom interaction is a central element in determining success in learning subjects through another language and therefore my primary interest was to observe, describe and analyse various types of interaction present in a CLIL classroom. In order to investigate classroom interaction in a CLIL environment I decided to adopt van Lier's interaction framework (van Lier 1988: $94-$ 120) together with its language functions (van Lier 1991: 48-64). All the data in this paper is a part of a PhD studies entitled "A Qualitative Evaluation of Content and Language Integrated Learning in Polish Secondary Education".

\section{DIFFERENT TYPES OF INTERACTION}

Relationships between learners and teachers are more formal and remote in some educational sectors than others. Crandall and Tucker (1990: 187-200) claim than such a social distance is often due to the subject matter of the course, the atmosphere at school and the attitude of individual teachers towards learners. In CLIL, the teacher may recognize that by teaching in a L2 he/she may be in a slightly disadvantageous position. This may be due to reduced personality syndrome or to the demand of being a good teacher. The notion of reduced personality refers to "a condition in which a person feels constrained when communicating in a language other than the mother tongue" (Appel, Muysken 1988: 46). What is more, in some schools, teachers report that they feel more dull or boring when teaching in the L2 because they "can't be themselves" (Marsh, Marsland 1999: 34). Additionally, they avoid being humorous because of L2 constraints and as a result they are perceived by the learners as very strict and serious people. In fact, CLIL facilitates movement towards learners adopting a more adult-adult relationship with the teacher who becomes a professional facilitator. In some schools where CLIL has been introduced, shift in the learner-teacher relationship can be noticed. The teachers rely on such techniques as lecturing and they do not try to be in close relationship with their learners. "If the CLIL context remains a classic adult-learner environment, in which the adult is the one who knows and the one who provides, with the learners in the role of passive recipients, then there are various variables which can upset the learning cli- 
mate" (Marsh \& Marsland 1999: 35). In fact, shifting the style towards shared experience or adult-adult help to cope with certain problems which may appear in the CLIL classroom.

Van Lier (1988: 94-120) established an interaction framework which I decided to adopt in my study. Van Lier (1988: 94-120) distinguishes four basic types of classroom interaction:

a). the teacher has no control over the topic and the activity;

b). the teacher controls the topic but not the activity;

c). the teacher controls the topic and the activity;

d). the teacher controls the activity but not the topic;

In a further development of this framework, van Lier (1991: 48-64) adds another dimension, namely the function of the language. He distinguishes three types of function:

a). ideational (telling people facts or experiences);

b). interpersonal (working on relationships with people);

c). textual (signaling connections and boundaries, clarifying, summarizing and revising);

The above mentioned types of interaction can also be observed in the CLIL classroom. However, one important issue should be brought in here, which may have a huge impact on classroom interaction, namely, learner autonomy. In a typical Polish language classroom, it is the teacher who is in the centre and therefore it is mainly teacher-learner interaction. In the CLIL classroom, the learner should be in the centre so the interaction shifts from teacher-learner to learner-teacher and learner-learner. In the autonomous CLIL classroom the starting point is not the textbook but the learners. The CLIL teacher recognizes that each member of the class has a history, interests, and emotional as well as educational and communicative needs. The teacher also recognizes that learning is not a simple matter of the unidirectional transmission of knowledge, skills, and expertise. On the contrary, "it is a process, where anything can be learnt in terms of what is already known" (Dam 2000: 38-55). Learner autonomy comes into play as learners begin to accept responsibility for their own learning (Fitzgerald, Morrall, Morrison 1996: 61), and this is what happens in the CLIL classroom. The CLIL learner becomes responsible for his own learning but within the limits imposed by what he/she already knows. It is worth a reminder that the autonomous approach insists that language is learnt partly "from the inside out," as learners attempt to express their own meanings for their own learning purposes. "In the autonomous approach, learning is anchored in the achieved identity of the individual learner and the interactive processes by which learners collaboratively construct their shared learning space" (Dam 2000: 38-55). 


\section{A SHORT PRESENTATION OF THE STUDY}

The study was conducted in one of the Secondary Schools in Kraków, Poland. One bilingual class was observed: learners at the age of 16-17 and three teachers for a period of one school year. The main study was preceded by a pilot study. Throughout the whole school year, I was taking part in all the lessons taught in English. The learners had two hours of geography, two hours of biology and three hours of mathematics per week. The bilingual syllabus was based on the National Polish curriculum for Secondary Schools and covered the same topics as the monolingual one. The method used for my study was observation which is a major data collection tool in a qualitative research. One observation sheet was prepared for the learners and one for the teachers. The observation sheet was divided into the following parts:

1. The stage of the lesson e.g. revision, brainstorming, etc.

2. Types of interaction:

a). the teacher has no control over the topic and the activity;

b). the teacher controls the topic but not the activity;

c). the teacher controls the topic and the activity;

d). the teacher controls the activity but not the topic;

3. Functions of interaction:

a). ideational;

b). interpersonal;

c). textual;

Initially, my intention was to record the classes, provide transcripts of the lesson and analyse the types of interaction on the basis of the recordings. Unfortunately, the headmaster of the school and the parents did not agree to have the lessons recorded. In this situation I decided to use the observation sheet.

\section{DATA PRESENTATION AND ANALYSIS}

Having observed the classes and having paid special attention to interaction, it can be said that as far as different types of interaction are concerned there were only small changes noticed. The following types of interaction were present during the CLIL lessons observed: type 1 when the teacher controls neither the topic nor the activity. This type of interaction was more often observed during the CLIL geography lesson due to the fact that the teacher was a tutor of that particular class and there were often a lot of additional topics concerning classroom activities such as trips or performances discussed during the subject lessons e.g. 


\section{TYPE 1}

\section{Geography}

T: "Today, I would like to finish the topic of glaciers"

L1: „Pani profesor, ja jestem nieprzygotowana do lekcji” [translation: “I'm not prepared for the lesson, professor"];

T: „Dobrze, ale może już zacznijmy lekcję bo mamy mało czasu” [translation: “OK, but maybe let's start the lesson because we are running out of time"];

L1: „Pani profesor, jeszcze jedno pytania, ile razy można być nieprzygotowanym do lekcji?” [translation: "How many times can I be unprepared for the lesson, professor?];

T: „Mówiłam na początku roku szkolnego" [translation: “I told you at the beginning of the school year"]

This type of interaction was also more often noticed at the end of the semesters when the CLIL learners wanted to discuss some matters concerning their marks.

Type 2, namely controlling the topic but not the activity occurred during all CLIL lessons observed e.g.

\section{TYPE 2}

\section{Biology}

T: "Now we are going to talk about the functions of the excretory system. You should make notes and I cannot see that you are making any"

One particular change noticed was connected with the frequency of this type occurring throughout the school year. This type of interaction was diminishing due to the fact that the CLIL learners got used to certain CLIL teachers' instructions and at the end of the school year they knew what to do and did not need a lot of instructions.

There were no changes observed concerning type 3 when the teacher controls both the topic and the activity. This was the most frequent type of interaction during the school year e.g.

\section{TYPE 3}

Mathematics

T: "So, making use of this diagram, could you please calculate it now? Susan, come to the blackboard"

Type 4 - controlling the activity but not the topic was especially observed at the beginning of the school year (in September and in November) when the CLIL learners could not settle in the new circumstances and often ended up talking in groups about something completely different. This 
situation could also have been caused by lack of vocabulary or misunderstanding e.g.

\section{TYPE 4}

Biology:

T: "Now, get into three groups and make a list of the different functions of water"

L: "Do we have to write it in points?"

T: "Well, yes, you should"

L: "Dobra, coś tam na pewno wymyślimy jak zapyta. Co zabieracie ze sobą na wycieczkę? [translation: “OK, we will definitely make something up when asked. What are you taking for the trip?"]

L: "Masz na myśli ubrania, albo co?" [translation: "Do you mean clothes or what?"]

At the beginning of the school year this type of interaction was often present on the CLIL classroom. However, a significant change was noticed at the beginning of $2^{\text {nd }}$ semester as well as in other months following February in which this type of interaction was hardly ever noticed. This change probably occurred due to the fact that the CLIL learners had more knowledge in English concerning particular topics and therefore there was less need to change the topic while working in groups or pairs. One very significant change should also be pointed out, namely the frequency of interaction between the CLIL teachers and the CLIL learners. In the $1^{\text {st }}$ semester there was much more interaction going on between the CLIL learners themselves than between the CLIL learners and the CLIL teachers. What is more, this interaction between the CLIL learners was usually in Polish and it was not connected with the topic of the lesson. Within time, it was noticed that the CLIL learners started cooperating more with other CLIL learners and also with the CLIL teachers in English, which was probably due to the fact that they started feeling more confident and had fewer problems with communicating in the foreign language.

Taking into consideration the functions of interactions mentioned, there was only a slight change noticed. In most cases, the functions of interactions between the CLIL learners and the CLIL teachers were ideational (telling about the facts or experiences) or textual (signalling boundaries, clarifying, summarizing and revising) e.g.

\section{IDEATIONAL FUNCTION}

Biology:

L: "I've heard we should drink a lot of water"

T: "Yes, you are right"

L: "And we should eat something sweet every day"

L: "Well, I suppose cakes are not very healthy, by the way what cakes do you like most?" 


\section{TEXTUAL FUNCTION}

Geography:

T: "To summarise, what should be taken into consideration when discussing different astronomical theories?"

Geography:

T: "Could you define the term universe. What is it?"

With time (around January) it was noticed that the interpersonal function of the interaction between the CLIL learners and the CLIL teachers was occurring more often. The CLIL learners were feeling more comfortable in the new environment and they were trying to work on their relationship with the CLIL teachers, which was a positive occurrence e.g.

\section{IDEATIONAL AND INTERPERSONAL FUNCTION}

Mathematics:

T: "Well, I will tell you an anecdote. Yesterday I was really surprised because there was a mouse in my house and I have a cat. I was sure that the cat would eat the mouse but it didn't. This morning I found them playing together"

$\mathrm{L}:$ "Oh, we don't believe it"

T: "Well, you should. A cat can be compared to the maths teacher and a mouse or rather mice to the pupils. Think about this anecdote and let's get back to our sets"

One more change concerning interaction should be pointed out, namely, it was noticed that at the beginning of the school year, interaction type 2 usually took place during the lessons of mathematics e.g.

\section{TYPE 2}

Mathematics:

"Put down the following definitions into your notebooks"

In many cases the CLIL mathematics teacher controlled the topic but did not control the activities going on. A lot of the CLIL learners seemed to have lost concentration and as a result they were working on their interpersonal interactions in Polish with other CLIL learners e.g.

\section{INTERPERSONAL FUNCTION}

Mathematics:

T: "Get into pairs and try to answer the following question: how can these two sets be joined?

L1: "Nie chce mi się już dzisiaj siedzieć w szkole. Chyba się zwolnię z w-fu” [translation: "I don't feel like staying at school today. I think that I will not go to physical education"]

L2: "Zostań, dzisiaj nie będziemy dużo ćwiczyć bo babka jest chora" [translation: "Come on, don't go, we won't exercise a lot because the teacher is ill"] 
This situation was caused by lack of understanding and the difficulty of the subject itself. However, gradually, the situation changed. Throughout the whole school year all types of interaction occurred during mathematics, especially type 3 when the CLIL mathematics teacher controlled both the topic and the activity e.g.

\section{TYPE 3}

Mathematics

$\mathrm{T}$ : "So, this is the price in the beginning and this is the fixed rate, can you please dictate what I should write now, anybody".

This change was also caused by the fact that the CLIL learners were acquiring more knowledge about mathematics in English and were becoming more interested in it.

\section{CONCLUSIONS}

To sum up, at the beginning of the school year CLIL could have a negative impact on CLIL learners interaction in a foreign language with the CLIL teachers and also other CLIL learners which was probably due to difficulty of the subjects (e.g. mathematics), the lack of vocabulary, insufficient selfconfidence and misunderstanding. In many cases the CLIL learners were afraid to speak in the foreign language and therefore it was mainly the teacher who was in the centre. However, throughout the whole school year, the situation was changing gradually and changes concerning interaction were visible. Type 1 when the teacher controls neither the topic nor the activity was only noticed at the end of the semesters when the learners wanted to discuss their marks or some other topics concerning particular classroom events. I suppose that this type of activity can also be noticed at the end of semester in regular classes and its occurrence has nothing to do with CLIL. Type 2 when the teacher controls the topic but not the activity was more frequent at the beginning of the school year which could be connected with CLIL. The CLIL learners had more problems with understanding the content of the subject at the beginning of the school year and therefore they could not do the activities properly. Type 3 when the teacher controls both the topic and the activity was more frequent in the $2^{\text {nd }}$ semester due to the fact that the CLIL learners had more content knowledge in the foreign language and were less afraid to speak. Type 4 when the teacher controls the activity but not the topic was observed at the beginning of the school year. The CLIL learners often ended up talking in groups (in Polish) which was caused by 
lack of proper vocabulary as well as language barrier. As for the functions of interactions discussed in the article, their occurrence is not that significant in CLIL as no particular changes have been observed during the school year and therefore no impact of CLIL could be noticed. All the functions of interactions were present through the whole school year.

The myriad of factors involved in FL classroom interaction can be a motivation for constant reflection and research on what really happens in a CLIL classroom. From a general perspective CLIL can be seen as a concept which changes the present school system in Europe because it is innovative and it has got a high potential to break down outdated pedagogical ideas, especially in the world where functioning without a good command of a L2 has become impossible (Wolff 2005). It also gives an opportunity for Polish teachers and learners to communicate with other teachers and learners from abroad, exchange experiences, conduct joint research of the problems and look at the problems from different angles, namely from the content perspective (subject matter), communication perspective (language learning and using), cognition perspective (learning and thinking process), and culture perspective (developing intercultural understanding and global citizenship) (Coyle, Hood, Marsh 2010: 41).

\section{REFERENCES}

Appel, R., Muysken, P., 1988. Language Contact and Bilingualism. London: Edward Arnold a division of Hodder \& Stoughton, 10-52.

Coyle, D., Hood, P., Marsh, D., 2010. Content and Language Integrated Learning. Cambridge: Cambridge University Press.

Crandall, J., Tucker, G.R., 1990. Content-based instruction in second and foreign languages. In: Padilla, A., Fairchild, H.H., Valadez, C. (eds.). Foreign language education: Issues and strategies. Newbury Park: CA: Sage, 187-200.

Dam, L., 2000. Why focus on learning rather than teaching? From theory to practice. In: Little, D., Dam, L., Timmer, J. (eds.). Focus on Learning rather than Teaching: why and how? Papers from the IATEFL conference on learner independence. Dublin: Trinity College Dublin, 38-55.

Faerch, C., Kasper, G., 1983. Strategies in interlanguage communication. London: Longman.

Fitzgerald, S., Morrall, A., Morrison, B., 1996. Catering for individual learning styles: experiences of orienting students in an Asian self-access centre. Autonomy 2000: the development of learning independence in language learning, 55-69.

Fruhauf, G., Coyle, D., Christ, I. (eds.), 1996. Teaching content in a foreign language. Practice and Perspectives in European bilingual education. Alkmaar: European Platform for Dutch Education, 172-187.

Hall, J.K., Verplaetse, L.S. (eds.), 2000 Second and Foreign Language Learning through Classroom Interaction. Mahwah, NJ: Lawrence Erlbaum, 1-15. 
Hall, J.K., Walsh, M., 2002. Teacher-student interaction and language learning. Annual Review of Applied Linguistics, 22, 186-203.

van Lier, L., 1988. The Classroom and the Language Learner. London-New York: Longman.

van Lier, L., 1991. Inside the classroom: learning processes and teaching procedures. Applied Language Learning 2, 48-64.

Marsh, D., Marsland, B. (eds.), 1999. Learning with Languages. A professional Development Programme for Introducing Content and Language Integrated Learning. Finland: University of Jyväskylä.

Papaja, K., 2010. A Qualitative Evaluation of Content and Language Integrated Learning (CLIL) in Secondary Education. Unpublished PhD thesis. Katowice: Institute of English, University of Silesia.

Wolff, D., 2005. Content and Language Integrated Learning in HAL. Volume 5, Chapter 21, 1-22. 